\title{
The Impact of Corporate Social Responsibility Disclosure on Firm Value
}

\author{
Ahmad Sopian ${ }^{1}$, Hadri Mulya ${ }^{2}$ \\ ${ }^{1}$ Mercu Buana University, School of Post Graduate. \\ Meruya Selatan Road, Jakarta, Indonesia \\ ${ }^{2}$ Mercu Buana University, School of Post Graduate. \\ Meruya Selatan Road, Jakarta, Indonesia
}

\begin{abstract}
This research is aimed to analyze Corporate Social Responsibility Disclosure toward the Firm Value.Dependent variable in this research was Firm Value related party tobins'q. Independent variables in thisresearch Corporate Social Responsibility Disclosure, This research used secondary data analysis of financialstatements or annual reports of exclude financial company and bank at Indonesia Stock Exchange in 2014 -2016. By using purposive sampling method, the total amount of samples obtained in this research were 201 from 67 companies. This research used data panel regression analysis method. The results of the analysis inthis research showed that Corporate Social Responsibility Disclosure didn't effect toward the firm value.
\end{abstract}

\section{Keywords: Corporate Social Responsibility Disclosure, and Firm Value.}

\section{Introduction}

The firm is any form of business that is running any type of business is both continuous and fixed and established, as well as work based in the territory of the Republic of Indonesia, for the purpose of gain or profit (and legislation The Republic of Indonesia number 3 year 1982 regarding the Mandatory list of companies in general provisions article 1 letter $b$ ). The objective of firm establishment is not only in maximizing firm's profit, but also to maximize the firm's value. When a firm focuses on maximizing profit, it usually ignores the social responsibilities, risks, and short-term goals.

The high value of the firm's will yield prosperity for shareholders, in that purpose that shareholders will invest to the firm ${ }^{(22)}$. With the increased value of the firm is high is a long-term goal that should have reached the firm that will be reflected in the market price of its shares, because the investor's assessment of the firm can be observed through the price movements of the firm's shares transacted on the stock exchange for firms that have gone public ${ }^{(19)}$. Market value for public firms is determined by the supply and demand mechanism in the stock exchange, which reflects in the listing price. Public Firm's market value is determined by independent institution such as service appraisers firm.

Essentially, the value of the firm can be resized through several aspects such as the price of the stock market because the market price of stocks reflects investors overall assessment of any equity owned. The price of the stock market also shows the central assessment of the entire market and act as a barometer of the performance of the firm management. If the value of a firm can be measured by stock prices, then the firm's market maximum value is equal to maximum price of the stock market. The wealth of the shareholders and the firm presented by the value of the Tobins' $Q$ is a reflection of the investment decision, funding, and asset management ${ }^{(22)}$.

PT Polychem Indonesia Tbk. closes of its plant in Karawang due its declining firm's value. This serves as one of many examples for investors how important a firm's value can be. Another factor that could be used by the firm to be able to increase the value of his firm is to do a corporate social responsibility program, Which at this time many firm are trying to increase the value of the firm by way of approaching the public.

Indonesia began developing Corporate Social Responsibility in 1990, marked by the emergence of definition of Corporate Social Responsibility by World Business Council for Sustainable Development 
(WBSD) in 1995. WBSD itself is an institution that is initiated by United Nations for business circles in order to be able to contribute to development. The context of sustainable development is a development concept that focuses on economic, social, and environmental aspects without damaging the natural resources (1). Corporate Social Responsibility has grown so significant that many firms include it as one of the business strategies. By implementing Corporate Social Responsibility, the firms can create a good image of giving rise to a positive assessment of consumers who are able to improve their loyalty towards the firms products (14).

Criminal sanctions concerning Corporate Social Responsibility implementation of the offences contained in Act No. 23 of the year 1997 on managing the environment article 42 paragraph (1) which States " "Whoever just because his willful conduct acts that result in pollution and destruction of the environment, is liable to a criminal the longest three years and a maximum fine of one hundred million dollars". Through Corporate Social Responsibility disclosure in the annual report, the shareholder and stakeholders can evaluate and assign the decision about how the company's Corporate Social Responsibility activities during the period from running. This is done in the company in hopes of obtaining a positive response from investors, so influential for the survival of the firm that became the financial strength of the company in the future.

Hendra (2014) wrote in Bangkapos.com the importance of Corporate Social Responsibility for society and exposed the environmental pollution caused by PT Timah. Due to the insistence of Dressing Village farmer's and Youth Movement South BANGKA (Basel), PT Timah Tbk Production Region IV, Toboali, shut down the mine in the village of 601, South Bangka Regency. Head of Production Supervisor IV, Toboali, Sigit Wibowo said, the closure is done at the insistence of the people. Mistakes committed by its partners, which pollute the rice paddies with mine and held PT Timah reponsible for the damage. If the calculated loss, we lose. But for the benefit of shared, we will close the mine 601, "says Sigit to bangkapos.com, Thursday (20/3/2014), after holding a dialogue in the Office of Regent South Bangka. Dresser Village, farmers complained of sewage irrigation drains and into the paddy fields, resulting in inability to produce a good crops.

The firms that do not implement Corporate Social Responsibility can suffer losses and decreasing in value. There are many firms in Indonesia that hasn't applied Corporate Social Responsibility and its disclosure on the annual report. Corporate Social Responsibility Disclosure of Corporate Social Responsibility is needed to reflect the firms accountability_in providing information to stakeholders, therefore related to the potential of Corporate Social a great responsibility and the benefits demonstrated the need for good governance structure a firm disclosure practices and to promote Corporate Social Responsibility towards the better ${ }^{(3)}$. Then the better disclosure of Corporate Social Responsibility will provide better consumer loyalty that will also have an impact on the increased sales that provide added value for the firm.

Corporate Social Responsibility Disclosure is is useful to provide a signal of goodnews to investors that this firm has performed well, ultimately increasing investor's interest towards the firm, which is demonstrated by the increase in the value of the firm and its stock price. ${ }^{\left({ }^{17}\right)}$. Corporate Social Responsibility Disclosure by the firm constitutes consideration for investors or prospective investors whether to infuse capital in the company or not. When a corporate has a good image in the community, there will be built a reputation the company so that it can increase the value of the company. ${ }^{(21) .}$

Based on these problems then conducted this research with the aim to find out the influence of Corporate Social Responsibility disclosure, against the value of the company.

\section{Literature Review And Development Hypothesis Stakeholder Theory}

The theory of Stakeholders (Stakeholder Theory) declare all parties, internal and external, that can affect or is affected by the company either directly or indirectly. Stakeholders are the group or individual who can affect or is affected by a specific goal achievement ${ }^{(10)}$. As such, the stakeholder is internal and external parties, such as: Government, competitors, local communities, international environment, 
institutions outside the company (NGOs and the like), the observer the environment, workers, minorities and others whose existence is very affecting and affected companies ${ }^{(\mathbf{1 6})}$.

The stakeholder theory suggests that the company should pay attention to stakeholders, as they are the party which affects and is affected either directly or indirectly, for the activity as well as the policy taken and carried out the company. If the company does not pay attention to stakeholders is not possible will reap the protests and can eliminates the legitimacy of stakeholders ${ }^{(\mathbf{1 6})}$.

Stakeholder theory is based on as followed :

1. The corporation has relationship with many constituency groups (stakeholders) that effect and are affected by its decisions ${ }^{(8)}$.

2. The theory is concerned with the nature of these relationship in terms of both processes and outcomes for the firm and its stakeholders.

3. The interests of all (legitimate) stakeholders have intrinsic value, and no set of interests is assumed to dominate the others ${ }^{(4,5)}$.

4. The theory focuses on production management decision making ${ }^{(\mathbf{5})}$.

Based on the basic assumptions of stakeholder theory, the company cannot escape with the social environment (social settings). Companies need to maintain legitimacy of stakeholders as well as settling it within the framework of policies and decision making, so as to support the achievement of the objectives of the company, namely the stability of enterprises and guarantee of going concern. ${ }^{(16)}$.

\section{Signalling Theory}

Signaling Theory stated that if company's executives have better information about the company, they would be compelled to convey such information to potential investors in order to make the stock price the company increased ${ }^{\mathbf{2 0})}$. For example, the management generally has complete and accurate information compared to the external companies regarding the factors that affect the value of the company. Unreliability of information, or information asymmetry, will occur if the management does not fully convey all the information that's pivotal for the company to increase their value in the capital markets. The lack of information concerning the company will cause the external parties to act cautious, resorting to protect themselves by giving a low price for the company.

The company can increase the value of the company by way of reducing the information asymmetry. One way to reduce the information asymmetry is to give a signal to external parties. When the management delivered information to the market, then the market will generally respond to such information as a signal that indicates good or bad news against the existence of the event that can affect the value of the company. This occurrence will reflect on the change in price and the volume of company's share. Signaling theory suggests how a company should give signals to users of the financial and non-financial. The signal is in the form of information on what has been implemented or carried out by the management to fulfill the objective of the owners to maximize their profits.

Signals can be either promotional or other information that states that the company has a better performance compared to its competitors. Based on the theory of signaling, environmental and social activities provide information to investors about the prospect of a substantial return in the future. Disclosure of Corporate Social Responsibility and appropriate expectations of stakeholders as a signal in the form of good news that's given by the management to the public, which provide not only the information that the company has good prospects in the future but also to ensure the creation of Sustainability Development. The company conducts disclosure of Corporate Social Responsibility in hopes of improving the reputation and the value of the company ${ }^{(18)}$.

\section{Review Of The Literature \\ The Value Of The Company}

The value of the company is the price payable by prospective buyers when the company is sold. If a company has a better value, the chance of getting a higher prosperity will be available for the owner of the company ${ }^{(10)}$. While keown ${ }^{(12)}$ describes that firm's value is the perception of investors against the company's level of success that associated with the stock price. The high share price makes the value of a company is also high. 
In the theory of the firm, the company's main objective is to maximize the wealth or value companies (firm value). For shareholders, maximizing the value of the firm is very important for a firm, because a maximum firm's value also means a better prosperity for the stakeholders. The firm's stock price is the market reaction to the overall condition of the firm as a reflection of the firm's value is realized in the form of the firm's stock price.

Tobin's Q method is formulated by James Tobin, a Nobel Prize winner from the United States. Tobin's $\mathrm{Q}$ is the market value of the firm at a cost of successor's asset. According to the concept, the Q ratio is superior to the ratio of the market value because it focuses on how the current value of the firm's against how much it costs needed to replace it at this time. In practice, the $\mathrm{Q}$ ratio is hard to assess accurately because estimating the replacement cost of the assets of a firm is not an easy job ${ }^{(7)}$. Several advantages of using measurements of the ratio of Tobin's Q are:

1. Estimating the potential development of the share price;

2. Estimating potential management capabilities in managing the assets of the company;

3. Estimating potential investment growth ${ }^{(2)}$.

\section{Corporate Social Responsibility}

The World Business Council for Sustainable Development (WBCSD) defines Corporate Social Responsibility as an ongoing commitment among business to behave ethically and contribute in economic development at the same time improving the quality of the workforce and family life as well as local communities and society as a whole (16) defines "Corporate social responsibility (CSR) is about how companies manage the business processes to produce an overall positive impact on society."

\section{Corporate Social Responsibility Disclosure}

Disclosure of social responsibility according to ${ }^{(9)}$ is "the process of social and environmental impacts of communication of economy and organizational activity against a special group of interested parties and a community as a whole ". The negative contribution of the company towards the surrounding environment has led to a loss of public confidence, therefore, by disclosing information about the company's operations with respect to the environment as a responsibility of the company is expected to restore public confidence. So, in order to inform the stakeholders that the company has done their social responsibility, company annual record should disclose it as additional information.

The concept of reporting on Corporate Social Responsibility which is conceived by GRI is the concept of sustainability report that emerged as a result of the existence of the concept of sustainability development. In the sustainability report used method of triple bottom line, which measures not only from an economic point of view but also from social and environmental point of view. This idea is the result of the presence of three impact company operations, namely economic, social, and environmental.

Corporate Social Responsibility is calculated based on the amount of net income of the company and shared with 91 indicators based on GRI-G4. In the standard GRI-G4 performance indicator is divided into 3 main components, namely economic, environmental, social and employment practices, the convenience of work, human rights, community, and responsibility for the product.

\section{Hypothesis}

Implementation of the strategy of Corporate Social Responsibility and such disclosure in the annual report will be able to produce the practice of Corporate Social Responsibility is good and will yield the value of the company high due to the presence of added value to the company. Disclosure and practice Corporate Social Responsibility shows the company's commitment to care for the environment within the existence of the company's practice in order to get a better expected value from investors ${ }^{(\mathbf{1 5})}$.

Based on framework expressed above, then there is the hypothesis in this study can be formulated as follows:

H1 : Disclosure of Corporate Social Responsibility has a significant effect to the value of the company.

\section{Research Methodology}


Quantitative method is a method of research based on the philosophy of positivism, used for researching on population or a particular sample. Researchers used random sampling technique and instrument research used as the data collection method data analysis quantitative in nature or statistics with the aim to test the hypothesis that has been established. The study of causal (causal study) is a study where researchers want to find out the cause of several problems ${ }^{(\mathbf{1 9})}$. Method research will quantitative research with the causal approach. This research aims to know the implication of the influence of the nature of cause and effect between two or more variables. And for the independent variables, namely disclosure of corporate social responsibility, will analyze on good corporate governance and the return on assets estimation and their influence to the value of the company.

Methods of analysis used is regression of the data panel with the help of Eviews 10. Then the regression equation used is as follows :

$$
\mathrm{Q} i t=\alpha+\beta 1 \mathrm{CSRDI} i t+\varepsilon \text { it }
$$

$\begin{array}{ll}\mathrm{Q} \text { it } & \text { : The Value Of The Company (Tobin's Q) } \\ \text { CSRDI } & \text { : Corporate Social Responsibility Disclosure Index } \\ \mathrm{i} & \text { : Entity to }-\mathrm{i} \\ \mathrm{t} & \text { : Period to-t } \\ \alpha & : \text { Constants } \\ \beta 1 \ldots \beta 3 & : \text { The regression coefficient } \\ \mathcal{E} & \text { : Error terms } \\ \text { Populations and Samples }\end{array}$

The population of the region consists of: the object/subject that has certain characteristics and quantity specified by researchers to study and then drawn the conclusion. While Sample is a part of the number and characteristics of the population owned ${ }^{(31)}$. The population used in this study is included in the compass Index 100. Determination of the companies sampled in this study using the method of purposive sampling. Purposive sampling is one of the non random sampling methods where researchers specify sampling by way of setting attributes in accordance with the specific research objectives so hopefully can answer problems research. As for the sample is selected based on the following criteria:

1. Company located at the compass Index 100 during the period 2014-2016;

2. Companies in the index 100 Compass which publishes annual reports in a row during the period 2014 - 2016;

3. Companies in the index of Compass 100 operating outside the areas of banking and finance;

4. The company is on the 100 Compasses Index published financial statements expressed in rupiah and ends on December 31, 2014 - 2016 period. This is due to the movement of the exchange rate which is very volatile and unstable at the time of the study period lasts;

5. Companies in the Index that has 100 Compass completeness of data about corporate governance and disclosure report of social activities during the period from $2014-2016$;

Data on use is secondary data and the collection of data is done through the methods of documentation in Indonesia Stock Exchange official website www.idx.co.id. The data processing is done by E Views 10 student version used to describe whether or not there are influences between variables.

\section{Data Collection.}

Data collection methods is used by researchers in obtaining data and other information in order to conduct smooth research. In this research, data and other information related to this research obtained using data collection techniques as follows :

1. Field Research.

Field research is conducted as documentation method. Researchers did data gathering techniques by using records that have been there as well as the relevant documents to support this research. This research 
is done by accessing the website www.idx.co.id (Indonesia stock exchange official website) as well as a few websites that's relevant to support this research.

\section{Research Libraries}

This method is conducted by reading, studying and reviewing books, internet, journals and literature from some earlier research. Another method is manually search the data in the format of a paper printout, which consists of journals, books, theses, and thesis-related research is to obtain information that can support.

Methods of Data analysis Ekananda ${ }^{(6)}$ says that the data panel is a set of data that contains the sample data of individuals (households, companies, district/city, etc.) on a specific time period. Then Lela ${ }^{(\mathbf{1 3})}$ says that the data is panel data that has a characteristic cross section and time series simultaneously ${ }^{(6)}$. explained that in general, the use of panel data is capable of delivering excellence in statistics or in economic theory, among other things:

1. Panel data is able to take into account the heterogeneity of individuals explicitly by allowing individual-specific variables used in the equation Econometrics.

2. The ability to control each individual heterogeneity, in turn making the data panel can be used to test and build a model of more complex behavior. For example, the phenomenon of economic scale or technology changes that will be examined using data panel than with pure data cross-section or timeseries.

3. If the specific effect is significantly correlated with other explanatory variables, then the use of panel data will reduce the issue of omitted-variables substantially.

4. Because it is based on the observation that repeated cross-section data, then the excellent panel used for the study of dynamic adjustments such as the mobility of the workforce, the rate of transitions of the work, and others.

5. With the increasing number of observations, then it will have implications for data that is more informative, more markedly, kolinieritas between the variables on the wane, and increased degrees of freedom (degree of freedom) so that the results can be obtained more efficient estimation.

6. The further development of data analysis the panel dedicated to the previous model, aimed at the time data for one individual to be the analysis of a few individuals. For example Vector Autoregression Exogen (VARX) at a State Panel VARX to some countries, Error Correction Model $(\mathrm{ECM})$ in a province into a Panel of ECM for several provinces, Vector Error Correcion Model (VECM) into Panel VECM, Simultaneous equations on a country becomes Simultaneous Panels for some countries in certain regions and others.

\section{Results And Discussion \\ The Description Of The Object Of Research}

The object of this study is that companies based in Indonesia and is listed on the Indonesia stock exchange index 100 compass. As for the industry from the object of this research consists of industry- Automobiles \& Parts: 3 companies, Construction \& Materials: 10 companies, Electronic \& Electrical Equipment company: 1, Fixed Line Telecommunications company: 1 company, Food Producers: 10 companies, General Retailers: 7 companies, Health Care Equipment \& Services: 1 company, Industrial Engineering company: 1 company, Industrial Transportation companies, Media companies: 5 companies, Mining: 4 companies, Mobile Telecommunications companies, Oil \& Gas Producers: 1 company, Personal Goods: 2 companies, Pharmaceuticals \& Biotechnology 1 company, Real Estate Investment \& Services: 12 companies, Support Services: 1 company, Technology Hardware \& Equipment: 1 company; Tobacco: 1 company, Travel \& Leisure: 1 company.

That all the companies in the sample of this research is a company that has a good extreme low liquidity, high market capitalization, fundamental, as well as the good performance of the company ${ }^{(11)}$. 
Tabel 1

Descriptive Statistics

\begin{tabular}{|l|c|c|}
\hline & TBQ & CSRDI \\
\hline Mean & 1.761244 & 0.349801 \\
\hline Median & 1.000000 & 0.270000 \\
\hline Maximum & 17.65000 & 1.000000 \\
\hline Minimum & 0.380000 & 0.020000 \\
\hline Std. Dev. & 2.351548 & 0.224140 \\
\hline Skewness & 3.666178 & 0.881139 \\
\hline Kurtosis & 18.63807 & 3.056941 \\
\hline & & \\
\hline Jarque-Bera & 2498.368 & 26.03673 \\
\hline Probability & 0.000000 & 0.000002 \\
\hline \multicolumn{2}{|c|}{} & 70.31000 \\
\hline Sum & 354.0100 & 10.04779 \\
\hline Sum Sq. Dev. & 1105.956 & 201 \\
\hline Observations & 201 & \\
\hline
\end{tabular}

Table 1 above shows that Tobins'Q is a measurement used to measure the value of the company to obtain good results against an enterprise value of descriptive statistics output. Results TBQ over a period of 3 years from the year of 2014th up to 2016 with number $\mathrm{N}$ as much as 201. The highest value of TBQ 17.65000 i.e. PT Unilever Indonesia (2014), while the lowest value is 0.380000 i.e. PT Exploitable Energy Indonesia (2014), the middle value 1.000000 and average value TBQ is 1.761244 . with standard deviation is 2.351548 .

Corporate Social Responsibility Disclosure Index (CSRDI) is a ratio used to measure the level of corporate responsibility towards society and the environment that's caused by company's day-to-day operational activities. CSRDI calculated using the dummy variable 1 if the items disclosed in the annual report and 0 if the item is not disclosed in the annual report. ranging from 2014 until 2016 with the amount of $\mathrm{N}$ is 201. The results of the output value of the descriptive statistics of the Supreme CSRDI of 1. 000000 i.e. PT Single ICT Prakasa (2016), while the lowest value is amounting to 0.020000 i.e. PT Exploitable Energy Indonesia (2014), the middle value of 0.270000 , and $r$ value align ata-CSRDI is of 0.349801 , with a standard deviation of 0.224140 .

\section{Tabel 2. Fixed Effect Model}

\begin{tabular}{|c|c|c|c|c|}
\hline \multicolumn{5}{|c|}{ Dependent Variable: TBQ } \\
\hline \multirow{2}{*}{\multicolumn{5}{|c|}{$\begin{array}{l}\text { Method: Panel Least Squares } \\
\text { Date:05/23/18 Time:20:38 }\end{array}$}} \\
\hline & 8 & & & \\
\hline \multicolumn{5}{|c|}{ Sample: 20142016} \\
\hline \multicolumn{5}{|c|}{ Periods included: 3} \\
\hline \multirow{2}{*}{\multicolumn{5}{|c|}{$\begin{array}{l}\text { Cross-sections induded: } 67 \\
\text { Total panel (balanced) observations: } 201\end{array}$}} \\
\hline & & & & \\
\hline \multicolumn{5}{|c|}{ White cross-section standard errors \& covariance (d.f corrected) } \\
\hline Variable & Coefficient & Std. Error & t-Statistic & Prob. \\
\hline $\mathrm{C}$ & 11.41889 & 2.133142 & 5.353084 & 0.0000 \\
\hline \multirow[t]{2}{*}{ CSRDI } & -2.454597 & 1.577278 & -1.556223 & 0.1221 \\
\hline & Effects Sp & cification & & \\
\hline \multicolumn{5}{|c|}{ Cross-section fixed (dummyvariables) } \\
\hline R-squared & 0.867111 & \multicolumn{2}{|c|}{ Mean dependent yar } & 1.761244 \\
\hline Adjusted R-s quared & 0.797116 & \multicolumn{2}{|c|}{ S.D. dependent var } & 2.351548 \\
\hline S.E. of regression & 1.059199 & \multicolumn{2}{|c|}{ Akaike info criterion } & 3.221313 \\
\hline Sum squared resid & 146.9693 & \multicolumn{2}{|c|}{ Schwarz criterion } & 4.371718 \\
\hline Loglikelihood & -253.7420 & \multirow{2}{*}{\multicolumn{2}{|c|}{$\begin{array}{l}\text { Hannan-Quinn criter } \\
\text { Durbin-Watsonstat }\end{array}$}} & 3.686817 \\
\hline F-statistic & 12.38820 & & & 2.643473 \\
\hline Prob(F-statistic) & 0.000000 & & & \\
\hline
\end{tabular}

Table 2 explains that Corporate Social Responsibility Disclosure of has no significant effect. The Rsquared value is high enough that is as big as 0.867111 or of $86.71 \%$

Determination of Coefficient Test (R2) 
Determination of Coefficient Test (R2) is conducted to measure how far the ability of independent variables namely Corporate Social Responsibility Disclosure in the dependent variable that is explained the value of the company. Adjusted R square value shows 0.797116 or $79.71 \%$. These results show that variation of variable disclosure of Corporate Social Responsibility, able to explain of $79.71 \%$ variation variable the value of the company. Then of $20.29 \%$ points out that the existence of other variables, which explain the variations in the variable the value of the Company that are not included in the panel data regression model in this study (table 3 ).

\section{Test Statistic F}

Statistical tests are performed to understand how big the influence of Corporate Social Responsibility Disclosure variable. The value of $F$ is acquired for 12.38820 with a level of significance of 0.000000 . This result indicates that the regression model is used because it is less than the significance level 0.05 . Then it can be made the conclusion that the model used for this is good and very decent used (table 3)

\section{Statistical Tests T}

Statistical tests T done to know the influence of Corporate Social Responsibility Disclosure individually against the value of the company. The results of the analysis on this panel data regression method show that the value of the constant is 11.41889 , then the regression coefficient values of Corporate Social Responsibility Disclosure (CSRDI) is registration-2.454597, (table 4)

\section{Tabel 3}

\section{Uji Koefisiensi Determinasi $\left(\mathbf{R}^{2}\right)$ \& Uji Statistik F}

\begin{tabular}{|c|c|c|c|}
\hline \multicolumn{3}{|c|}{ Cross-section fixed (dummy variables) } & \multirow[b]{2}{*}{1.761244} \\
\hline R-squared & 0.867111 & Mean dependent yar & \\
\hline Adjusted R-s quared & 0.797116 & S.D. dependent yar & 2.351548 \\
\hline S.E. of regression & 1.059199 & Akaike info criterion & 3.221313 \\
\hline Sum squared resid. & 146.9693 & Schwarz criterion & 4.371718 \\
\hline Log likelihood & -253.7420 & Hannan-Quinn criter. & 3.686817 \\
\hline F-statistic & 12.38820 & Durbin-Wats on stat & 2.643473 \\
\hline Prob(F-statistic) & 0.000000 & & \\
\hline
\end{tabular}

\section{Tabel 4}

Iii Ctatictil $\mathbf{T}$

\begin{tabular}{|c|cccc}
\hline Variable & Coefficient & Std. Error & t-Statistic & Prob. \\
\hline \hline CSRDI & 11.41889 & 2.133142 & 5.353084 & 0.0000 \\
\hline & -2.454597 & 1.577278 & -1.556223 & 0.1221 \\
\hline
\end{tabular}

\section{Discussion}

Corporate Social Responsibility disclosure variable has no significant effect to the value of the firm because the not many investors pay attention to or consider the disclosure of corporate social responsibility of the Firm as one of information that affects them in their investment. Investors pay more attention to the good financial performance in investing.

Another factor which makes disclosure of corporate social responsibility is not a significant effect due to the tendency of investors in buying shares. Investors are more likely to buy shares in order to obtain a capital gain (increase in the stock price) and investors tend to buy and sell shares on a daily basis (the daily trader), regardless of the existence of the company in the long term. Investors also prefer stocks with view on market economy and news items that appear. Whereas corporate social responsibility is a long-term business strategy in an effort to maintain the sustainability of the company and increase the value of his 
company, therefore the influence of corporate social responsibility will not have any significant effect in the short term.

Then researchers found the average low level of disclosure of corporate social responsibility of the company that made this research sample. The average disclosure corporate social responsibility amounting to $34 \%$ is because of the low awareness of most companies concerning the long-term positive impact from the implementation of corporate social responsibility. Another one is the lack of confidence of investors that the application of corporate social responsibility that the company raised in completely funded entirely as a form of corporate social responsibility and concern for the environment surroundings, because investors still looking at companies that run corporate social responsibility programs cost the company recognized as the burden of the current year or in operating expenses and will have an impact directly with the decline in the company's revenue, so the greater the charge issued to corporate social responsibility program fewer corporate earnings, which reduced income tax also reduced then that will be paid to the Government so as not to exert influence on the value of the company in public.

\section{Conclusions}

Corporate Social Responsibility Disclosure does not affect the value of the company. this is because investors are paying more attention to a good financial performance in investing, then investors are more likely to buy shares in the to obtain a capital gain (increase in the stock price) and investors tend to buy and sell shares on a daily basis (the daily trader), regardless to the long-term sustainability of the company. And the researchers found the average low level of Corporate Social Responsibility disclosures of 34\%. The lack of confidence of investors that the application of corporate social responsibility that the company raised in completely funded entirely as a form of corporate social responsibility and concern for the environment the surroundings.

\section{Limitations and Suggestions}

\section{Limitations}

Researchers have conducted this research to its full potential. However, researchers realized that there are still many limitations, among others:

a) Variables that affect firm value contains only Corporate Social Responsibility disclosure, Corporate Social Responsibility Measurement comes from a single source, namely the annual report. Target sampling is less than 100 the company and duration observations is limited only to 3 years;

b) Existence of limited research using a published financial reports to the public does not show the real state of affairs;

c) This research cannot represent the entire companies listed on the Indonesia stock exchange.

\section{Suggestions}

Based on the results of the discussion and the conclusions above, researchers can provide suggestions as follows:

a) Subsequent researchers are expected to include more variables, large number of samples, and a longer observation period so that the level of the $\mathrm{R}$ Square research can be much higher considering there are still variables that unexplained in this research such as the size of the company, market share etc.

b) Companies should remain consistent implementing Corporate Social Responsibility Corporate Social Responsibility even though it doesn't affect the value of the company, because the company still has to be responsible for managing the impact caused by operations;

c) Investors are expected to anticipate the development of Corporate Social Responsibility Disclosure because there are some companies who deliberately raise and better Corporate Social Responsibility Disclosure, on the annual report and financial statements to provide insight of the company's promising prospect; 
d) For future researches where this can be a reference for an advanced research in order to gain more informative and accurate results.

\section{References}

[1] Bambang dan Melia. 2013. CSR (Corporate Sosial Responsibility). Rekayasa Sains, Bandung.

[2] Bambang Sudiyatno dan Elen Puspitasari. 2010. Tobin's Q dan Altman Z - Score Sebagai Indikator Pengukuran Kinerja Perusahaan (Tobin's Q and Altman ZScore as Indicators of Performance Measurement Company). Kajian Akuntansi, Vol 2 No 1. ISSN : 1979-4886

[3] Bayoud, N \& Kavanagh, M, 2012. Corporate Social Responsibility Disclosures : Evidence From Libyan Managers. Global journal of business research, volume 6, number 5, University of Southern Queensland.

[4] Clarkson, M.B. (1995). A stakeholder Framework for Analyzing and Evaluating Corporate Social Performance. Academy of Management Review.

[5] Donaldson, T. and Presston, L. (1995). The stakeholder Theory of The Corporation: Concepts, Evidence, Implications. Academy of Management Review.

[6] Ekananda, Mahyus. 2016. Analisis Ekonometrika Data Panel (2 ${ }^{\text {th }}$ Ed). Jakarta: Mitra Wacana Media.

[7] Farah Margaretha. 2014. Dasar-dasar Manajemen Keuangan. Jakarta: PT Dian Rakyat.

[8] Freeman, R. E. 1984. Strategic Management: A Stakeholder Approach, Boston, Pitman.

[9] Hery. 2012. Akuntansi \& Rahasia dibaliknya untuk Para Manajer Non Akuntansi. Jakarta: PT Bumi Aksara.

[10] Husnan, Pudjiastuti Enny. 2012. Manajemen Keuangan, Edisi Keenam, UPP STIM YKPN, Jakarta.

[11] Jogiyanto Hartono. 2016. Teori Portofolio dan Analisis Investasi. Edisi Kesepuluh. BPFE UGM, Yogyakarta.

[12] Keown, J Arthur. (2012). Manajemen Keuangan : Prinsip-Prinsip dan Aplikasi. Edisi 10. Jakarta : Indeks.

[13] Lela Nurlela Wati. (2017). Metodologi Penelitian Bisnis Terapan Aplikasi SPSS, EVIEWS, Smart PLS, dan AMOS. Jakarta : CV Mujahid Press.

[14] Lutfiah Amanti. 2012. Pengaruh Good Corporate Governance Terhadap Nilai Perusahaan dengan Pengungkapan Corporate Sosial Responsibility sebagai Variabel Pemoderasi. Jurnal Akuntansi Universitas Negeri Surabaya Vol. 1 No.1.

[15] Nurlela, Rika dan Islahudin. (2008). "Pengaruh Corporate Social responsibility Terhadap Nilai Perusahaan Dengan Prosentase Kepemilikan Manajemen Sebagai Variabel Moderating" (Studi Empiris Pada Perusahaan yang terdaftar Di Bursa Efek Jakarta). Simposium Nasional Akuntansi XI Pontianak 23-24 2008.

[16] Nor Hadi. 2014. Corporate Social Reponsibility. Yogyakarta: Graha Ilmu.

[17] Putra, R.W. (2013). Analisa Pengaruh Pengungkapan Good Corporate Governance dan Corporate Social Responsibility terhadap Kinerja Keuangan dan Nilai Saham Perusahaan di Indonesia : Studi Empiris terhadap Perusahaan Property dan Real Estate di BEI pada Tahun 2009 - 2011. STEKPI School of Business, Universitas Trilogi.

[18] Restu Warno Putra. 2015. Financial Constraint: Evidence from Indonesia American Journal of Economics, Finance and Management Vol. 2, No. 4, 2016, pp. 44-48 ISSN: 2381-6864 (Print); ISSN: 2381-6902 (Online).

[19] Reny dan Priantinah. 2012. "Pengaruh Good Corporate Governance dan Pengungkapan Corporate Social Responsibility terhadap Nilai Perusahaan (Studi Empiris pada Perusahaan yang Terdaftar di Bursa Efek Indonesia periode 2007-2010)". Jurnal Nominal (Universitas Negeri Yogyakarta), Volume 1, Nomor 1, tahun 2012 hal.84-103.

[20] Ross, S.A., 1977. "The Determination of Financial Structure : The Incentive Signalling Approach", Journal of Economics, Spring, 8, pp 23-40.

[21] Shabrina Widyanti. 2014. “Analisis Pengaruh Kinerja Keuangan, Pengungkapan Corporate Social Responsibility, dan Good Corporate Governance terhadap Nilai Perusahaan (Studi Empiris pada 
Perusahaan Manufaktur yang terdaftar di Bursa Efek Indonesia Periode Tahun 2009-2012)". Skripsi. Manajemen. FEB. Universitas Diponegoro.

[22] Sri Hermuningsih, 2013. Pengaruh Profitabilitas, Growth Opportunity, Struktur Modal Terhadap Nilai Perusahaan Pada Perusahaan Publik Di Indonesian. Buletin Ekonomi Moneter dan Perbankan. Oktober 2013.

[23] Sugiyono. 2014. Cara Mudah Menyusun: Skripsi, Tesis, dan Disertasi. Bandung: Alfabeta. 